\title{
Mariátegui e a Revolução Russa
}

Bernardo SoAREs

RESUMO: O presente artigo tem o objetivo de analisar a relação existente entre uma das maiores figuras do marxismo latinoamericano, o peruano José Carlos Mariátegui, e o processo político de maior impacto no século $\mathrm{XX}$, a Revolução Russa. Para tal, atentarse-á tanto às análises do autor sobre os acontecimentos na Rússia revolucionária, através de seus escritos produzidos ao longo dos anos e em distintos momentos da vida, abrangendo da juventude à maturidade, quanto aos reflexos que a construção do socialismo gerou em seu pensamento, expandindo os horizontes de suas formulações teóricas e proposições políticas.

PALAVRAS-CHAVE: José Carlos Mariátegui; Revolução Russa; América Latina.

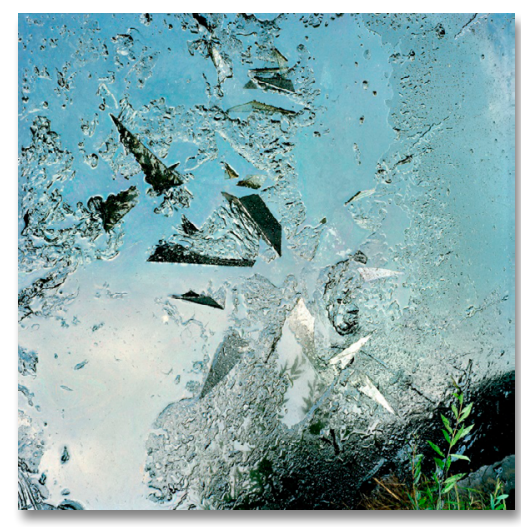

\section{Mariátegui and the Russian Revolution}

\section{$\overline{\text { BERnARDo SOARES }}$}

Professor de História do Instituto Federal de São Paulo (IFSP). Mestre em História pela Universidade Federal Fluminense. E-mail: bernardo.soares@ifsp.edu.br.
ABSTRACT: This article aims to analyze the relationship between one of the greatest figures of Latin American Marxism, the Peruvian José Carlos Mariátegui, and the most impactful political process in the twentieth century, the Russian Revolution. To do so, one will look at both the author's analysis of events in revolutionary Russia through his writings produced over the years and at different moments of his life, ranging from youth to maturity, as well as the reflections that the construction of socialism generated in his thinking, expanding the horizons of his theoretical formulations and political propositions.

KEYWORDS: José Carlos Mariátegui; Russian Revolution; Latin America.

RECEBIDO EM: $17 / 07 / 2017$ APROVADO EM: 20/12/2017 


\section{APRESENTAÇÃO'}

O pensamento de José Carlos Mariátegui tem sido, nos últimos anos, alvo de crescentes interesses por parte dos pesquisadores brasileiros. Ainda que muito de seus escritos já tenham sido vertidos ao português e, na academia, já se notem valorosas contribuições para o entendimento do autor em questão, há ainda importantes pontos de seu pensamento a serem iluminados. ${ }^{2}$

No que diz respeito ao tema desse artigo, é imprescindível destacar que, desde 2012, como viabilidade de aprofundamento na leitura de Mariátegui sobre a Revolução Russa, os curiosos sobre a contribuição do jornalista peruano podem consultar uma coletânea com alguns de seus escritos sobre a Revolução de Outubro e seus desdobramentos, traduzida e organizada por Luiz Bernardo Pericás, que também assina um ótimo prefácio, sob o título de "Revolução Russa: histórica, política e literatura". Contudo, esse esforço inicial ainda não gerou pesquisas de maior fôlego sobre o tema, fato que se espera ser revertido, na ocasião do centenário da tomada do poder pelos bolcheviques.

Nesse sentido, o presente texto busca contribuir para o avanço do entendimento da vida e da obra de Mariátegui, assim como discutir, num aspecto mais amplo, os impactos da Revolução Russa na intelectualidade latino-americana, através dos escritos de um de seus maiores expoentes. Para tanto, analisar-se-á a produção do autor acerca da temática, abrangendo o período que se estende desde sua juventude, mais especificamente o início do ano de 1918, primeira vez em que o jovem jornalista de vinte e quatro incompletos anos transparece, de maneira indireta, seu conhecimento sobre os acontecimentos que ocorriam do outro lado do mundo, até 1930, quando denunciava as movimentações

\footnotetext{
1 Trabalho apresentado em sua forma embrionária no Colóquio Internacional Marx e o Marxismo, de 2017. Nos anais do evento, é possível encontrar uma versão inicial desse artigo.

2 Para uma visão panorâmica acerca da fortuna da obra de José Carlos Mariátegui no Brasil, aconselha-se a leitura do artigo de Pericás (2010), no qual o autor trabalha a influência e, sobretudo, a ausência de Mariátegui nas reflexões da intelectualidade brasileira. Desde a publicação do artigo, pode-se dizer que bastante se avançou nos estudos brasileiros sobre o jornalista peruano, já concretizado em dezenas de artigos e em algumas dissertações e teses.
} 
internacionais contra a União Soviética, já em suas últimas semanas de vida. Ademais, serão considerados como materiais de estudo não somente os textos produzidos pelo marxista peruano, mas também os publicados por outros autores na revista Amauta, por ele dirigida desde 1926 até sua morte. Nela, podem-se encontrar dezenas de análises que confluíam para a formação de seu pensamento e contribuíam para seu trabalho de exposição da realidade russa para além das versões retratadas pela grande imprensa.

Os jornais peruanos, infelizmente, não contam com um sistema de arquivo online que permita ao pesquisador buscar referências desde outras partes do mundo. Afortunadamente, o site de El Comercio conta com uma acanhada seção histórica que publica trechos diários contendo algumas notícias que foram matérias há cem anos. Dela, foram tirados os artigos necessários para descrever o posicionamento da grande imprensa peruana frente à Revolução Russa. ${ }^{3}$ Sobre seus escritos juvenis, suas correspondências e os demais textos da sua fase madura, foi consultado Mariátegui (1994a; 1994b), editado por Minerva na ocasião do centenário do autor. Como seus escritos estão mais acessíveis ao público através das edições populares de Obras Completas, sempre que possível também é feita referência à localização dos textos nessa obra. ${ }^{4}$ A revista Amauta, que funcionou entre 1926 e 1930, pode ser acessada na internet. ${ }^{5}$ Para o artigo, a análise se deu até o número 29, última publicação com Mariátegui em vida. A revista resistiria ainda por mais dois números sob a batuta de Ricardo Martinez de la Torre.

A exposição do artigo segue uma divisão tradicional já consagrada no que diz respeito às etapas evolutivas do desenvolvimento do pensamento de Mariátegui, a saber, a divisão de sua vida em três tempos: seu período de juventude marcado pelo trabalho jornalístico; seu período de vivência na Europa, entre os anos de

3 Caso interesse aos pesquisadores, esses trechos ainda podem ser achados em <http://elcomercio.pe/opinion/efemerides>. Acesso em: 16 abr. 2018.

4 As Obras Completas de Mariátegui podem ser consultadas em: <https://www. marxists.org/espanol/mariateg/oc/index.htm>. Acesso em: 16 abr. 2018.

5 Disponível em: <http://digital.iai.spk-berlin.de/viewer/>. Acesso em: 16 abr. 2018. 
1919 e 1923, de fundamental importância para a ampliação de suas referências teóricas e políticas; e o que se estende desde sua volta ao Peru até sua morte, em que se concentra a grande maioria de seus escritos relacionados aos desdobramentos acarretados pela Revolução de Outubro. Sem desconsiderar as diferenças entre os escritos e o processo de maturação do autor, devido destaque será dado ao liame que unifica as diferentes análises.

Ademais, importante ressaltar, o presente texto não tem a pretensão de esgotar as possibilidades de estudo acerca do tema. Tratando-se de um autor marxista e revolucionário como Mariátegui, não é equivocado afirmar que a Revolução Russa se apresenta como um tema que permeia praticamente todo o seu pensamento, direta ou indiretamente, uma vez que sua reflexão sempre esteve relacionada a projetos políticos que tiveram a Revolução Bolchevique como sua principal referência. Assim, poder-se-ia estender as reflexões do artigo a temas como sua concepção sobre o marxismo, sua visão sobre a forma de partido, a questão agrária e camponesa, etc - objetos, no entanto, já alvo de análises de outros autores que podem ser encontrados nas referências finais. Para o presente artigo, será considerada a discussão específica sobre a Revolução Russa em si e a construção do socialismo na Rússia, que, acredita-se, pode fornecer elementos para elucidar discussões mais amplas sobre o pensamento do autor.

\section{AS PRIMEIRAS REFLEXÕES}

Os primeiros textos de Mariátegui em que se podem ver comentários acerca da situação política russa tratam o tema de maneira oblíqua, não se referindo diretamente aos feitos de Lenin e seus partidários, mas revelando a cruzada antibolchevique que já se desenhava na política e nos grandes meios de comunicação limenhos. ${ }^{6}$ Assim, em 9 de abril de 1918, Juan Croniquer, um de

6 De todos os escritos de Mariátegui, os juvenis são os de mais difícil acesso ao pesquisador brasileiro. Esses textos não compuseram a edição popular de Obras Completas, em 20 volumes, que há algum tempo já foram disponibilizadas para consulta na internet. Apesar dos textos aqui mencionados serem importantes para acompanhar a evolução do autor sobre a Revolução Russa, também 
seus pseudônimos, publica no jornal El Tiempo um texto de título "Bolchevique, aqui", o qual iniciava comentando as frequentes censuras que sofria pelo fato de supostamente ser bolchevique, ainda que no artigo o tema central fosse comentar a declaração feita pelo deputado Victor Maúrtua reivindicando-se socialista. Apesar de não demonstrar conhecimento acerca da cena russa nem vincular sua simpatia à alcunha de bolchevique a uma visão política revolucionária, em meio à forte campanha anticomunista instaurada em seu país, seu posicionamento de jamais se dissociar das acusações proferidas deve ser visto como progressista (MARIÁTEGUI, 1994b, p. 3121).

Não foi com indiferença que a imprensa peruana acompanhou a fortuna do povo russo desde a revolução de fevereiro. A julgar pelas matérias publicadas no jornal El Comercio, um dos de maior expressão naquele período, a instauração de um governo liberal foi acompanhada com entusiasmo pelas classes dominantes peruanas. Ainda em 14 de março de 1917, enquanto se desenrolava a trama russa, o jornal anunciava a abdicação do czar como consequência de um vigoroso movimento revolucionário que se alastrava pelas principais regiões russas e que terminara em uma grande confraternização entre os soldados e a população em armas.

A linha editorial do periódico peruano confirma o que Boris Koval (1990 apud PERICÁS, 2012) afirmou de maneira mais abrangente para toda a América Latina. Ainda que a incerteza pairasse e que as informações não estivessem demasiadamente claras, a grande imprensa latino-americana, afirma o historiador, saudou a derrubada do czar e a chegada de Kerenski ao governo.

Mas por aí pararam os cumprimentos. Em menos de dois meses após os eventos que instauraram o governo provisório, o jornal peruano, informado pela agência Reuters, já dava como questão de tempo a sua derrocada. Os alvos, agora, eram aqueles que insistiam em desestabilizar o governo por não reconhecer sua legitimidade política e por criar espaços de duplo poder. A maneira como

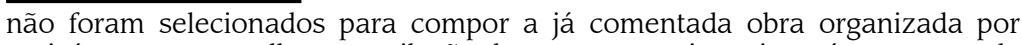
Pericás (2012). A melhor compilação dos seus textos juvenis está no tomo II de Mariátegui (1994b), que serviu de base para o artigo. 
os sovietes eram retratados seguia a linha da grande imprensa internacional, mostrando-os como instrumentos de sublevação da marinha e do exército e, quando não, colaboradores da Alemanha. A preocupação, nesse sentido, referia-se tanto ao medo da saída da guerra da Rússia quando à possível revolução socialista, fatos que pareciam apenas como que aguardando o melhor momento de rebentar.

Desconhecem-se registros de escritos de Mariátegui desses meses que se referem diretamente aos acontecimentos. Como dito, a primeira vez que delineia o tema é em abril de 1918. Ainda nesse mesmo mês, no dia 24, volta a abordá-lo, ocasião em que comenta a nomeação de Victor Maúrtua ao cargo de ministro da fazenda. Interessante notar que, ao se referir ao político, Mariátegui caracteriza-o com uma expressão que, anos mais tarde, tomaria para si, a de um "socialista convicto e confesso".

Ainda teria que se aguardar quase um ano para que o jornalista se expressasse de maneira mais contundente sobre o assunto. Como as ideias não estão isoladas da realidade que as cercam, não seria coincidência que ganhassem tornos mais definidos em um momento de ebulição política no Peru. Em janeiro de 1919, mais precisamente no dia 12, é publicado em El Tiempo um artigo em cujo título lia-se "El maximalismo cunde" (MARIÁTEGUI, 1994b), que não somente saudava a onda de manifestações operárias que ocorriam em toda a América Latina e no Peru, especialmente nos centros operários de Lima e Callao, como as relacionava aos ventos que sopravam de Moscou.

Os biógrafos de Mariátegui concordam em identificar esse período como um momento de estímulo de uma grande sensibilidade para com as causas sociais. A partir de então, seus textos ganham características cada vez mais incendiárias, trabalhando o autor de maneira impetuosa em sua underwood, denunciando as agressões truculentas do governo em relação aos manifestantes. Suas ideias começam a se mostrar grandes demais para um jornal como El Tiempo, que já havia sinalizado, ainda em junho de 1918, que não respaldaria seu funcionário caso sofresse algum tipo de retaliação por parte do governo, o que provocou o envio de uma carta de José Carlos para seu diretor, Pedro Ruiz Bravo (a mesma 
pessoa a quem, em 1923, enviaria uma elogiosa carta propondo a compra do jornal), acusando-o de comportamento reticente e desleal. $^{7}$

A saída, pois, seria desligar-se do diário e fundar o seu próprio periódico, junto ao amigo César Falcón, em maio de 1919. La Razón, de orientação claramente simpática aos movimentos populares e operários, não demoraria a colecionar opositores, dentre os quais o mais ilustre era o presidente Augusto B. Leguía, que acabara de assumir o governo naquele abril e que, em pouco mais de três meses de funcionamento do jornal, decidiu fechá-lo e condenar à prisão os seus responsáveis, pena que seria comutada com o envio dos dois jornalistas para trabalharem na Europa, uma espécie de "exílio" de luxo de que Mariátegui saberia usufruir.

\section{O APRENDIZADO EUROPEU}

Decerto as questões políticas abertas em seu país sob o influxo da Revolução Russa fervilhavam na cabeça do jovem periodista, enquanto se encontrava a bordo do Atenas, rumo ao Velho Mundo, naqueles dias de outubro de 1919. Os anos em que viveu na Europa (1919 - 1923) foram marcados por uma intensa ebulição política, basta lembrar que desse lapso datam eventos como a fundação da Internacional Comunista, a insurreição espartaquista na Alemanha, as ocupações de fábricas e, em contrapartida, o ascenso do fascismo na Itália, não desconsiderando todo o clima pós-Guerra que imperava no continente. Nenhum desses acontecimentos passou incólume ao arguto jornalista sempre atento às movimentações políticas, o que se pode notar nos diversos textos que escreveria desde então, nos quais os feitos do país dos sovietes guardariam lugar especial.

A Revolução Bolchevique chega a José Carlos de múltiplas maneiras. Pode-se dizer que, de modo indireto, analisa-a através das lentes da vida política italiana, notadamente das discussões no

7 A polêmica pode ser vista na correspondência de Mariátegui a Pedro Ruiz Bravo de 25 de junho de 1918. Todas as cartas de Mariátegui referidas ao longo do artigo podem ser encontradas no tomo I de Mariátegui (1994b). Esta, em especial, pode ser localizada na página 1684. 
interior do Partido Socialista Italiano. Em janeiro de 1921, acompanha como correspondente peruano do jornal El Tiempo, o mesmo de que havia pedido demissão, o histórico Congresso de Livorno, que marcaria a ruptura do Partido Socialista e a criação do Partido Comunista da Itália, cujos líderes e linha política se encontravam em maior consonância com os ideais dos bolcheviques e da Internacional Comunista. Acompanhando o desenlace das discussões, o peruano manifestaria sua simpatia pelo grupo que se congregava em torno do jornal L'Ordini Nuovo, cujo membro mais célebre, Antonio Gramsci, não seria mencionado nos seus escritos daquele momento. ${ }^{8}$

Chama-lhe atenção também o clima de cruzada anticomunista existente na Europa. Da mesma forma com que, anos antes, pôde perceber na pele a tática de difamação através da acusação sistemática de bolchevique por parte dos grandes meios de comunicação, Mariátegui reagiu frente à campanha aberta pela imprensa italiana contra Mihály Károlyi, ex-primeiro ministro da efêmera República Democrática Húngara, que fora expulso de seu exílio na Itália por supostas relações com os russos. ${ }^{9}$

Contudo, seria em três textos que o socialista peruano encararia de maneira frontal a tarefa de analisar o país de Dostoiévski. Poucos meses após sua chegada em Roma, em fevereiro de 1920, escreveria "La entente y los Soviets", em que analisava a relativa abertura dos países ocidentais em relação à Rússia socialista. Esse posicionamento não significava um gesto de bondade para com os comunistas, senão o reconhecimento da forte pressão popular europeia em defesa das causas socialistas, da demonstração de força do Exército Vermelho e da imperiosa necessidade de se

8 Há um bom número de trabalhos que buscam traçar paralelos entre Gramsci e Mariátegui, alguns, inclusive, suscitando a possibilidade de terem se conhecido pessoalmente. Ainda que essa última questão não tenha sido até hoje documentada, Mariátegui faz algumas referências a Gramsci ao longo de sua vida. Se, nos textos de sua estadia na Itália, não menciona o dirigente sardo, em Defesa do Marxismo, destaca Gramsci e Terracini como dois dirigentes políticos perseguidos pelo fascismo italiano.

9 Trata-se do texto "El conde Karolyi, expulsado por bolchevique", que, apesar de ter sido publicado em El Tiempo de 21 de junho de 1921, foi escrito em março daquele ano (MARIÁTEGUI, 1994b, p. 779). 
comercializar com o maior produtor de grãos do mundo. Ainda assim, não deixava de atentar para o fato de que não se tratava de um arrefecimento do assédio imperialista, senão uma mudança de tática. Com esse espírito, escreveria, em outubro daquele mesmo ano, "Rusia y Polonia", dando relevo especial às manobras das grandes potências que se utilizaram das disputas entre os dois países para promoverem uma guerra contra os bolcheviques. $\mathrm{O}$ terceiro artigo, "El hambre en Rusia", é de agosto de 1921 e nele chama atenção para a situação calamitosa em que viviam cerca de 10 milhões de russos, assim como o boicote promovido pelos países aliados, que encontrava contrapartida na solidariedade de operários de todo o mundo, que não mediam esforços em campanhas de ajuda ao país do socialismo. ${ }^{10}$

Em todos esses textos, Mariátegui nunca deixa de mencionar nomes russos que seriam referências recorrentes ao longo de sua vida. No aspecto cultural mais geral, sua paixão pela literatura levar-lo-ia a admirar figuras como Nikolai Gógol, Liev Tolstói, Fiódor Dostoiévski e Maximo Gorki. O último, único da nova geração de escritores russos que mencionaria nessa época, contava com um apreço tão grande por parte de Mariátegui que motivou nele uma viagem até Saarow Ost, pequeno lugarejo alemão onde o escritor russo descansava, para a realização de uma entrevista. Da conversa, mediada e traduzida pela esposa de Gorki, o peruano extraiu não apenas as informações necessárias para escrever um artigo sobre o romancista em seu primeiro livro publicado, como igualmente tomou da ocasião outra noção igualmente defendida por outros autores naquele momento de pós-Guerra, que era a percepção da decadência da civilização europeia. ${ }^{11}$

Não somente os artistas como também as figuras políticas chamaram a atenção do socialista peruano. Nomes como Vladimir

10 Todos os artigos mencionados no parágrafo estão agrupados sob o título Cartas de Italia, que compõe o $15^{\circ}$ volume das Obras Completas de Mariátegui. Para o artigo, foi consultado Mariátegui (1994a), onde os artigos escritos na estadia italiana concentram-se entre as páginas 735 e 828.

11 Trata-se do livro La escena contemporánea, publicado originalmente em 1925 e volume 1 de Obras Completas. O artigo em questão intitula-se "Máximo Gorki y Rusia", que pode ser encontrado na página 998 de Mariátegui (1994a). 
Lenin, Leon Trotski e Grigori Zinoviev podem ser facilmente encontrados em seus escritos do período europeu, sendo os dois primeiros constantemente apontados como os grandes dirigentes do processo revolucionário, entendimento que se estendeu ao longo dos anos. Foi igualmente nesse momento que Mariátegui pôde ter acesso a leituras sobre a Revolução Russa, em particular, e sobre o marxismo, em geral, que o acompanharam até o fim de sua vida.

No que resta da biblioteca pessoal de Mariátegui, em uma pesquisa feita em julho de 2014, este pesquisador encontrou textos de John Reed sobre a sociedade russa pós-revolucionária ${ }^{12}$ e de dirigentes políticos como Leon Trotski, ${ }^{13}$ Karl Radek, ${ }^{14}$ Nicolai Bukharin, ${ }^{15}$ Zinoviev ${ }^{16}$ Lenin $^{17}$, entre outros, grande parte adquirida enquanto vivia na Itália. Essa é só uma parte daquilo que ainda sobra do acervo pessoal do autor disponível para consulta na Casa Museo Mariátegui, uma vez que grande parte de seus pertences foi subtraída durante as várias batidas policiais em sua casa, assim como outra parcela considerável daquilo que foi preservado encontra-se descentralizada em outras bibliotecas peruanas.

Em uma importante obra destinada a estudar a formação intelectual de Mariátegui, trabalhada detidamente na biblioteca do autor, Vanden (1975) menciona outras significativas obras do pensamento marxista que serviram de arcabouço teórico para o peruano, tais como o volume I d'O capital em italiano e sua edição francesa em 11 tomos, e, também nessa língua, Teorias da Maisvalia e A Miséria da Filosofia, além de uma versão em espanhol de $A$ Revolução Espanhola, de Marx. De Engels, contava com um exemplar francês de Socialismo Utópico e Socialismo Científico.

12 Tradução italiana de O conselho de fábrica na Revolução Russa e Como funciona o Soviet.

13 Tradução italiana de Organização do exército vermelho e Terrorismo e comunismo: anti-Kautsk, além da tradução francesa de Novo Curso.

14 Tradução ao italiano de A luta pelo controle operário e ao espanhol de Ditadura do proletário e terrorismo.

15 Tradução italiana de Programa do Partido Comunista e francesa de Os problemas da Revolução Chinesa.

16 Tradução italiana de Doze dias na Alemanha.

17 Edição italiana de O Estado e a Revolução e A ditadura operária e o renegado Kautsky, além da francesa de Imperialismo, fase superior do capitalismo. 
Entretanto, por mais que se informasse e aumentasse seus conhecimentos acerca da realidade russa e do marxismo, a vivência europeia forneceu-lhe não mais do que os instrumentos iniciais para a formação de seu pensamento. Seria, pois, em sua volta ao país natal que Mariátegui escreveria seus textos mais importantes acerca da revolução bolchevique e sobre o socialismo, neste momento, não mais do ponto de vista do jovem intelectual sedento de conhecimento, mas do organizador político e cultural, que lia os acontecimentos do outro lado do mundo à luz de suas próprias experiências e necessidades políticas.

\section{DE VOLTA AO PERU}

Não passariam muitos dias, desde sua chegada ao Peru, no dia 17 de março de 1923, para Mariátegui iniciar seu labor de propagandista; desta vez, com novos elementos e uma formação política totalmente distinta do jovem que agitava desde as tribunas da imprensa há poucos anos. Em um país marcado pela fraca presença de organizações trabalhistas e onde o socialismo, até então, se apresentava como uma ideia bastante abstrata, o trabalho de organização política perpassou um longo caminho, trajetória na qual seria necessária a formação intelectual, cultural e ideológica de novos quadros.

Em uma das primeiras entrevistas concedidas desde o seu regresso, José Carlos foi questionado sobre a ideia de crepúsculo da civilização, que já havia sido apresentada aos leitores peruanos, em 16 de dezembro de 1922, em um artigo de sua autoria publicado em Variedades, o qual iniciava fazendo alusão à noção empregada por Gorki e dava continuidade esboçando o cenário caótico da Europa arrasada do pós-Guerra. Em outra entrevista, concedida a Claridad em 19 de maio do ano de seu desembarque, o entrevistador, sendo direto, perguntaria a impressão do entrevistado sobre a Rússia, uma vez que, no Peru, predominavam as ideias de um regime bárbaro e sanguinário. A resposta de Mariátegui já delineava o caminho de seu futuro trabalho: sobre as impressões em seu país, não hesitou em creditá-las ao desconhecimento da 
literatura pró-soviética, posto que a opinião pública era formada exclusivamente pelas leituras antibolcheviques. ${ }^{18}$

Justamente com o objetivo de fornecer ao público peruano visões cerceadas pelos grandes monopólios de comunicação, não somente as que diziam respeito à Rússia, mas à conjuntura internacional de maneira geral, o socialista aceitou o convite de Victor Raúl Haya de la Torre, para ministrar uma série de conferências na Universidade Popular González Prada. Assim, em 15 de junho de 1923, uma grande quantidade de estudantes e operários se amontoaram na sede da Federação dos Estudantes, para escutar uma palestra intitulada "La revolución social en marcha a través de los diversos pueblos de Europa", mas que passou às obras de Mariátegui sob o título "La crisis mundial y el proletariado peruano", nome que talvez sintetize de maneira mais clara e direta o objetivo apresentado tão logo nas primeiras palavras: difundir entre o proletariado peruano o conhecimento da crise mundial, que, até então, vinha sendo sistematicamente ocultado pela imprensa. Uma citação breve talvez possa definir o sentido pelo qual o trabalho de Mariátegui se guiaria nos próximos anos:

El proletariado necesita, ahora como nunca, saber lo que pasa en el mundo. Y no pueda saberlo a través de las informaciones fragmentarias episódicas, homeopáticas del cable cotidiano, mal traducidas y peor redactadas en la mayoría de los casos, y provenientes siempre de agencias reaccionarias, encargadas de desacreditar a los partidos, a las organizaciones y a los hombres de la Revolución y desalentar y desorientar al proletariado mundial. (MARIÁTEGUI, 1994a, p. 844 - 855)

Foi essa convicção que balizou as dezesseis conferências seguintes. No momento, interessam apenas as três que versaram diretamente sobre a Revolução Russa: "La revolución rusa"; "Exposición critica de las instituciones del régimen ruso"; e "Elogio de Lenin". ${ }^{19}$ Na primeira, o peruano delineia um panorama bem

18 Essa entrevista, publicada sob o título de "El Ocaso de la Civilización Europea", pode ser entrada na edição facsímile de Claridad.

19 Tais conferências compõem o $8^{\circ}$ volume das edições populares de Obras Completas. Das 17, apenas 9 mantêm o texto completo. Das demais apenas 
factual e elementar da história da Revolução Russa, exposição que o próprio autor admite como básica, reconhecendo que, para um público habituado a uma livre circulação de ideias, não representaria grande novidade, mas que, para o seu país, ainda se caracterizava como uma revelação. Interessante notar como Mariátegui novamente dá a algumas lideranças bolcheviques o papel de destaque, repetindo a lista que já havia sido exposta nos artigos escritos na Europa, encabeçada por Lenin, Trotski e Zinoviev, que, na ocasião, dirigia a Internacional Comunista. De Trotski, cita trechos do livro da Revolução de outubro à Paz de Brest-Litovsk, usado para preparar a aula. Mostra, ademais, conhecimento da própria imprensa burguesa na Europa e dos posicionamentos daquelas que mantinham correspondentes no país dos sovietes.

Em "Exposición critica de las instituciones del régimen ruso", a décima quarta conferência, proferida em 19 de dezembro de 1923, a exposição já se mostra mais robusta, adentrando pormenores do funcionamento da sociedade russa. Mariátegui trabalha com preocupação a relação entre o proletariado urbano e o campesinato, mostra-se apreensivo com essa tensão existente e saúda a Nova Política Econômica (NEP), como tentativa de desenvolvimento econômico da sociedade arrasada pela guerra e de contemplação dos anseios camponeses, ainda distantes do proletariado revolucionário.

Já a conferência sobre Lenin ocorre na semana do falecimento do líder bolchevique, mudando o planejamento inicial das conferências, para, assim, homenagear o revolucionário. Restam apenas poucas anotações sobre essa conversação, mas tudo indica que Mariátegui tenha somente apresentado traços biográficos do russo.

Dando seguimento ao trabalho propagandístico, Mariátegui ainda escreveu dezenas de artigos direcionados à divulgação do perfil dos principais líderes bolcheviques. Em seu primeiro livro

restam notas que serviram de base para a exposição ou resenhas publicadas nos meios de comunicação local. Os três artigos sobre a Rússia mencionados podem ser consultados no Tomo I de Mariátegui Total, respectivamente nas páginas $861-866$; $902-905 ; 912-914$. 
publicado, La escena contemporánea, de 1925, o autor reservaria uma seção para expor "fatos e ideias da Revolução Russa", voltando ainda ao tema na seção "revolução e inteligência", em que figurariam nomes de escritores como Gorki e Blok.

Nessa obra, fruto do pedido de amigos para elaboração de um panorama mais sistematizado de pequenos artigos escritos nos anos anteriores, é retomado tanto o esboço de dirigentes políticos já analisados, como Trotski e Zinoviev, quanto apresentado aquele a quem posteriormente Mariátegui trataria de maneira muito especial, o Comissário do Povo para Assuntos de Educação, Anatóli Lunatcharski. No que diz respeito ao criador do Exército Vermelho, destaca seus atributos teóricos, em especial seu trabalho de crítico literário (atividade também exercida por Mariátegui), ainda que ressaltasse que seus maiores feitos não estarem em seus escritos, mas em seu uniforme. No entanto, no artigo sobre Zinoviev, além de expor a árdua luta dos bolcheviques, encarnada na figura do dirigente da Internacional Comunista, contra o reformismo da II Internacional, termina por mencionar a polêmica já aberta no interior do Comitê Central do Partido Comunista da União Soviética (PCUS) que polarizou Zinoviev e Trotski. Nesse caso, Mariátegui encarou este como um dissidente eventual da teoria e prática bolchevique e se colocou ao lado da maioria do Comitê Central.

A fortuna de Trotski, no interior do partido bolchevique, já havia sido tema de discussão em um artigo publicado, no último dia de janeiro de 1925, em Variedades. Naquela ocasião, Mariátegui caracterizava a saída de Trotski do ministério como a mais ressonante queda de ministro, o que evidenciava não uma mera crise ministerial, mas uma crise partidária. O peruano mostrava-se bem informado acerca das críticas de Trotski ao Comitê Central do partido e das divergências em seu interior, o que chama atenção dada a dificuldade de circulação de informações naquele momento, sobretudo no Peru, onde o movimento comunista internacional não tinha representantes oficiais nem raízes históricas. Através das críticas apresentadas em Novo Curso, livro integrante de sua biblioteca, Mariátegui parece concordar com parte das posições que diziam respeito à necessidade de democratização 
do partido. Ademais, reconhece a autoridade moral da maioria do Comitê Central e afirma que, no meio de todas as movimentações políticas, estava claro que Trotski nunca havia conseguido se identificar com a velha guarda dos bolcheviques (MARIÁTEGUI, 1994a, p. 1075).

Sobre esse tema, o autor abordou-o novamente em duas outras ocasiões, em 1928 e 1929, quando as disputas no interior do PCUS mostravam-se cada vez mais acaloradas e a possibilidade de algum consenso entre as partes já não parecia possível. Na primeira, no artigo "Trotsky y la oposición comunista", foi justamente o sentido cosmopolita e internacional do organizador do exército vermelho, tão admirado por Mariátegui, que também o levou a condená-lo como inapto a dirigir o processo revolucionário em um momento em que não se tratava de estabelecer o socialismo no mundo, mas de realizá-lo em uma nação, características que Stalin, "um eslavo puro", encarnaria como ninguém (MARIÁTEGUI, 1994a, p.1189). Essa mesma avaliação foi retomada em "El exilio de Trotsky", obra na qual se mostra sensível à importância da crítica ao burocratismo e em que voltou a se posicionar favoravelmente àquilo que classificava como maior senso de realidade de Stalin e a maioria do partido (MARIÁTEGUI, 1994a).

Ainda que muitos analistas de Mariátegui se recusem a identificar a preferência da Amauta pelo posicionamento político de Stalin, o fato é que ela é realmente confirmada através dos textos, mostrando uma afinidade do autor com os grandes temas que estavam em discussão no interior do movimento comunista internacional. Em contrapartida, a postura sempre respeitosa em relação a Trotski não permite dizer que o peruano se posiciona de modo visceral nessa polêmica, que até hoje é capaz de suscitar paixões. Uma chave de leitura que se acredita ser a mais fértil para compreender a questão foi fornecida pelo próprio Mariátegui ao comentar Álvarez del Vayo (1929), cuja resenha foi publicada em 10 de julho de $1929 .{ }^{20}$ Nesse texto, o socialista diz que o fato

20 Inicialmente publicada em Variedades e complilada no volume 7 de Obras Completas, de título Signos e Obras. No tomo I de Mariátegui Total pode ser consultada entre as páginas 682 e 684. 
de o viajante espanhol admirar a figura de Trotski não o impediu de vislumbrar o valor do chefe da maioria. Dessa forma, para o próprio Mariátegui, concordar politicamente com as proposições políticas defendidas por Stalin não estava em contradição com o fato de continuar admirando o legado de seu rival (MARIÁTEGUI, 1994a).

Essa compreensão também pode ser notada na revista Amauta, em janeiro de 1927, aniversário da morte de Lenin, quando era publicado um texto de Trotski acerca do principal dirigente bolchevique e, no mês seguinte, era ilustrada com uma grande imagem de Stalin com os dizeres "líder do partido bolchevique".

Sobre os comentários de Mariátegui a respeito dos líderes soviéticos, Pericás (2012) afirma que, em diversos momentos, o autor assumiu uma postura unidimensional e laudatória, fato que o próprio historiador brasileiro tenta compreender inserindo-o no contexto da luta pela divulgação de fatos ocultados pela grande imprensa, o que pode tê-lo levado a supervalorizar os feitos soviéticos em alguns escritos. Com efeito, grande parte dos textos de Mariátegui é breve e expõe de maneira propagandística as lideranças bolcheviques. No entanto, o próprio autor sempre procurou dar voz àqueles que não concordavam necessariamente com suas posições, desde que apresentassem uma análise que considerasse objetiva do país de Lenin. Isso se aplica tanto aos textos que lhe serviram de base para a formação de sua visão, quanto aos publicados na revista Amauta.

Na constante busca pela ampliação de seu horizonte cultural, o autor serviu-se de uma extensa bibliografia para auxiliá-lo na compreensão do fenômeno russo. Na conferência ditada na Universidade Popular González Prada, por exemplo, foi capaz de mostrar conhecimento de trabalhos publicados na Europa sobre a Rússia, cujos autores não poderiam ser caracterizados como simpatizantes do bolchevismo, a exemplo do renomado H. G. Wells (1921), cujo livro não citado nominalmente seguramente era Russia in the Shadows, de sucesso na Europa. Os relatos de viagem à URSS lhe interessavam particularmente, pois sempre ansiava encontrar neles ricos detalhes em relação ao cotidiano do povo russo. Foi essa característica que elogiou no livro La otra Europa, 
escrito por Luc Durtain, resultado de uma viagem ao país em companhia de Georges Duhamel, nenhum dos dois revolucionários. Nesse caso, a visão considerada objetiva dos autores levaria Mariátegui a traduzir ao espanhol e publicar extratos do livro nos números 19 e 22 de Amauta, o primeiro destacando o avanço dos direitos das mulheres na URSS e o segundo das políticas públicas de educação e saneamento.

Até mesmo posições que concentravam maiores divergências se viram publicadas em Amauta, desde que fossem consonantes com os objetivos de seu diretor. Assim, se pode entender o artigo "La idea, los motes, los hechos", do colombiano Sanin Cano, publicado no número 10 do periódico, que seria veiculado em dezembro de 1927 - com um intervalo de sete meses da última edição, demora justificada pelo fechamento arbitrário da revista, que havia sido acusada pelo governo de complô comunista. Apesar de conter uma série de confusões a respeito do bolchevismo, como o fato de dissociá-lo das ideias de Marx e mostrá-lo como um fenômeno sem bases filosóficas, o texto, escrito por um autor caracterizado por Mariátegui como um liberal ilustrado, buscava mostrar à elite colombiana que o bolchevismo não representava um perigo naquele país. Nesse sentido, a sugestão serena parecia a Mariátegui útil para ser difundida em seu país, naquele momento de forte perseguição política.

Outro artigo com posicionamento conflitante ao de Mariátegui foi publicado nos números 20 e 21 da Amauta, em janeiro e março de 1929, assinado por César Ugarte, que, ao final do escrito, criticava a via insurrecional de tomada de poder e mostrava sua adesão às propostas gradualistas de ocupação de espaços institucionais. O próprio Mariátegui subscreve uma nota, ao fim da segunda parte do artigo, afirmando que, apesar de discrepar de Ugarte, sua exposição sobre os aspectos constitucionais e jurídicos da URSS mostravam que o fenômeno soviético não era nenhum absurdo.

Outros livros de viagem também mencionados por Mariátegui foram La Russie Nouvelle, de Edouard Herriot; o já referido livro de Álvarez del Vayo, também resenhado por Luis F. Bustamante no número 24 de Amauta, em maio de 1929, portanto, antes do artigo de Mariátegui; as notas de viagem de Stefan Zweig, 
também comentadas no número 24 de Amauta por Armando Bazán. Em Amauta, igualmente seriam publicadas crônicas de viagem de Carmen Saco, que posteriormente voltaria à Europa com uma credencial emitida pelo próprio Mariátegui, concedendo-lhe status de correspondente internacional de sua revista.

Além de trabalhar no sentido de possibilitar o acesso a fatos desconhecidos ao público peruano, Mariátegui, em diversos momentos, utilizou-se de sua pluma para articular um campo de defesa da pátria do socialismo, ante às iminentes ameaças de guerra imperialista. Ciente dos acontecimentos internacionais, o autor sempre deu bastante destaque às movimentações diplomáticas. No contexto dos tensionamentos do entre guerras, o peruano destacaria a postura dos soviéticos na Conferência de Genebra, para onde levaram a proposta de um desarme radical, rechaçada pelas demais potências. Quando do rompimento de relações da Inglaterra com a Rússia, Mariátegui minimizou o ocorrido, visto que a Inglaterra não resistiria por muitos anos à impossibilidade de comercialização com a Rússia, país que, aos olhos do peruano, já polarizava a história mundial com os Estados Unidos.

No entanto, o fato configurado como de maior preocupação e que resultou na mais intensa sequência de artigos foi a possibilidade de guerra entre Rússia e China, na qual as potências capitalistas estimulavam os chineses a invadirem o território russo. Nesse sentido, Mariátegui denunciou o trabalho de preparação psicológica feita pela grande imprensa em relação ao grande público com o objetivo de desenvolver um sentimento bélico antissoviético.

\section{PELA LITERATURA SOVIÉTICA}

A atividade de crítica literária acompanhou Mariátegui, ao longo de toda a sua vida. O que na infância se caracterizou como um dos poucos divertimentos ao alcance de uma criança com a saúde debilitada converteu-se em um ofício na juventude, quando se tornou conhecido em certos círculos literários da capital. Na Europa, teve acesso às mais recentes publicações do Velho Mundo, nas quais a nova literatura russa começava a ganhar destaque. Ao voltar ao Peru, uma de suas principais tarefas seria 
realizar um balanço crítico da literatura de seu país de origem, que pode ser visto na seção mais longa de sua magnuns opus (MARIÁTEGUI, 2010). Intitulado de "O processo da literatura peruana", esse balanço crítico literário fazia muito mais sentido pela acepção jurídica atribuída à palavra "processo" do que pela ideia de desenvolvimento como uma sequência de momentos.

Naquela obra, há uma passagem em que o marxista peruano expressa de maneira clara a relação que estabelecia entra literatura e política, o que nos parece sugestivo explicitar antes de passarmos às análises da literatura soviética em especial. Dizia o autor:

Mas isso não quer dizer que considero o fenômeno literário ou artístico de pontos de vidas extraestéticos, mas sim que minha concepção estética é unânime, na intimidade da minha consciência, com minhas concepções morais, políticas e religiosas e que, sem deixar de ser concepção estritamente estética, não pode operar independente ou diversamente. (MARIÁTEGUI, 2010, p. 223)

Dessa forma, não causa surpresa notar que as análises de José Carlos sobre os principais líderes da Revolução Russa, assim como da construção do socialismo naquele país, sempre estiveram em consonância com as avaliações literárias por ele produzidas. Os escritores russos sempre figuraram em sua lista de preferências. Em uma entrevista fornecida a Variedades, poucos dias após seu desembarque, em 1923, apontaria Gorki e Andreiev como seus principais romancistas, ao passo que Blok, diria ele, até pouco tempo antes era seu poeta favorito (MARIÁTEGUI, 1994a).

Do ponto de vista mais geral sobre a literatura russa, em diversas ocasiões, Mariátegui usou como alicerce de suas impressões o livro Literatura e Revolução, de Trotski, e os escritos de Ilya Ehrenburg sobre a literatura russa pós-revolução. Da primeira obra, incorporou a permanente preocupação de se analisar a literatura constantemente associada aos demais fenômenos históricos. Em relação ao segundo autor, que teria textos traduzidos e publicados na Amauta número 3, edição de novembro de 1926, Mariátegui, desde março do mesmo ano, já parecia demostrar afinidades tanto com a tese que condenava ao desprezo os autores soviéticos que 
optaram pelo exílio, quanto com sua predileção literária, exaltando escritores como Gorki, Blok e Maiakóviski, por exemplo.

A nova literatura russa, cujo caráter "épico" tanto agradava Mariátegui, era desconhecida em seu país, com a exceção de poucos nomes, tais como Gorki, Artsbachev, Andreiev e Merezhkovski. Portanto, em seu esforço de propagandear a sociedade soviética no Peru, Mariátegui ocupar-se-ia de difundir alguns escritores através de suas produções, escrevendo pequenas notas biográficas e publicando trechos de romances em Amauta. Assim, escreve artigos sobre Lidia Seifulina, Leonid Leonov, Mikhail Artsybashev, Sergei Essenin, Máximo Gorki, Konstantin Fedin, Nikolai Ognev, Larisa Reisner, Fedor Gladkov, Alexander Fadeiev e Alexander Blok. Em Amauta, publicou textos de Boris Pilniac ("Arina"), Isaac Babel ("La Sal e La Carta"), Mikhail Zoshchenko ("Una noche terrible"), Máximo Gorki (carta enviada a Romain Rolland e outra com a intenção de esclarecer sua suposta ruptura com os bolcheviques) e Larisa Reissner ("En los campos de la pobreza").

De suas preferências literárias e das obras publicadas em Amauta, o que se pode constatar é que o peruano tinha seu gosto literário claramente inclinado às obras do assim chamado realismo socialista. Ao comentar a obra de Feodor Gladkov, por exemplo, admirou-se com a história do protagonista de $O$ Cimento, que após prestar três anos de serviços ao exército vermelho se encontrava diante de sua mais árdua batalha: colocar a antiga fábrica de cimento de sua cidade natal de volta ao trabalho. Agradavam-lhe os romances cuja temática central retratasse de maneira realista as dificuldades da construção do socialismo. Distinguia a postura de Gladkov da de autores como Zola, por exemplo, que idealizava seus personagens. O realismo na literatura resultante da revolução socialista representaria a mais alta forma literária, análise esta responsável por levar Mariátegui a conjecturar a obra de Gladkov, alcançando o mesmo status e difusão de Tolstói, Dostoiévski e Gorki.

Percebe-se, portanto, como o autor vinculava, algumas vezes sem muitas mediações, sua concepção política e literária. Para o revolucionário socialista, a literatura deveria expressar os anseios das grandes massas populares. Essa mesma ideia o levaria a dizer que, em seu país, ainda não haveria uma literatura peruana, posto que tal atividade artística ainda não representava os $4 / 5$ de sua 
população, os indígenas, fato crucial para a construção da literatura nacional.

\section{A REVOLUÇÃO RUSSA NA REVISTA AMAUTA}

Ao longo do artigo, já se ressaltou a importância que a revista Amauta teve na difusão de temas relacionados à Rússia soviética. Analisando suas edições desde o seu lançamento até o número 29, último publicado com Mariátegui em vida, foi contabilizada quase uma centena de artigos que direta ou indiretamente abordavam temas vinculados ao país, quantidade demasiadamente expressiva, mas que, até hoje, parece não ter sido objeto de análise mais cuidadosa de seus estudiosos. ${ }^{21}$ Podem-se dividir os artigos em dois grandes grupos: 1) os que foram escritos por autores russos ou que abordavam temas sobre a realidade russa independente da nacionalidade do autor e 2) os que se vinculavam a organismos ligados ao Estado socialista. Em conjunto, permitem ao pesquisador enxergar uma dupla movimentação de Mariátegui, que ao final se complementam: a divulgação de notícias e nomes soviéticos ao público peruano carente dessas informações e uma aproximação política com o movimento comunista internacional.

A temática das publicações se apresentava bastante variada. Como visto, abundavam textos que versavam sobre literatura, que podiam ser desde esboços de interpretação da literatura soviética a contos ou extratos de romances. Normalmente, esse tipo de publicação costumava acompanhar artigos de Mariátegui publicados em outros meios acerca de seus autores. Nesse sentido, da mesma forma que se baseou em Ehrenburg para escrever uma crítica em março de 1926 e veiculou o autor na revista em novembro desse ano, em dezembro de 1928, publicou Durtain

21 A revista Amauta é, sem dúvida alguma, o empreendimento editorial de maior envergadura realizado por Mariátegui. Contudo, é importante destacar que o peruano esteve envolvido em outras iniciativas ao longo de sua vida, como a revista Labor, uma espécie de suplemento sindical de Amauta e Claridad, inicialmente dirigida por Haya de la Torre, a quem Mariátegui substituía em caso de ausência. Em ambas também é possível assinalar uma série de referências à Revolução Russa que se assemelham às expressas em Amauta. Um estudo sistemático do assunto nessas outras obras ainda é um trabalho a ser feito. 
ao mesmo tempo em que enviava uma crítica da obra à revista Variedades. Diversos outros livros analisados por Mariátegui tiveram apreciações de outros autores publicadas em Amauta, como a mencionada obra de Ognev, criticada por María Wiesse; o livro de Álvarez del Vayo, comentedo por Luis F. Bustamente; e os escritos de Zweig, criticados por Armando Bazán. Em geral, essas críticas coincidiam com o ponto de vista de Mariátegui, o que demonstra um forte intercâmbio de ideias, nos quais muitas vezes Mariátegui recebia sugestões de leitura e de autores através dessa rede de intelectuais colaboradores.

O peruano também tinha por hábito escrever a amigos, informando seus projetos de artigos ou então solicitando algum tipo de material. Em 11 de maio de 1925, por exemplo, enviou uma carta a Ricardo Vegas García, chefe de redação de Variedades, a quem informava naquele momento escrever um artigo sobre a novíssima literatura soviética e solicitava fotos de escritores como Pilniak, Maiakóviski e Blok, posteriormente encontradas por Mariátegui em uma revista italiana.

Em Amauta, também se publicavam fotos e gravuras de personalidades soviéticas. A primeira publicação sobre o tema foi justamente uma imagem de Felix Dzerzhinsky, o fundador da Cheka, sobre quem a imprensa internacional não poupava injúrias. Semanas antes dessa edição da revista, logo em seu número de lançamento, o peruano havia escrito um artigo a respeito do dirigente, classificando-o como um das figuras mais heroicas da revolução. O mesmo método foi utilizado na ocasião da morte de Leonid Krasin, que se tornou tema de artigo de Mariátegui de dezembro de 1926, menos de um mês após sua morte, e teve uma imagem com uma pequena nota de pesar na quarta edição de Amauta, publicada em janeiro do ano seguinte.

Na revista, também se publicavam obras mais densas, como trechos de Tratado de materialismo histórico, de Bukharin e Materialismo e Empioricritismo, de Lenin, o que demonstrava o alcance da formação teórica de Mariátegui. Nos momentos de alteração da política soviética, como ocorreu com o fim da NEP, orientação sempre defendida por Mariátegui, e o estabelecimento dos planos quinquenais, Amauta também serviu de palco para 
a exposição dessas modificações, contando, permanentemente, com o beneplácito de seu editor chefe. Dessa maneira, nos números 27 e 29, foram publicados relatórios oficiais da URSS sobre temas da economia, o que demonstra uma aproximação do peruano com a linha política oficial da URSS em um de seus debates de maior envergadura.

O outro eixo de publicação já mencionado anteriormente foi justamente a difusão de resoluções políticas de órgãos vinculados à URSS. Dentre eles, destaca-se o grande número de artigos produzidos pela Liga contra o Imperialismo e pela Confederação Sindical Latino-americana. Importante destacar que para Mariátegui esses dois organismos tinham importância vital, uma vez que o primeiro vinculava-se à sua disputa no Peru com o líder da Aliança Popular Revolucionária Americana (APRA), Haya de la Torre - aquele mesmo que havia aberto as portas da UPGP em 1923, mas que agora se encontrava em outro campo -, pela direção do movimento anti-imperialista peruano. ${ }^{22}$ Dessa forma, supõe-se que o reconhecimento pela Liga contra o Imperialismo, que Mariátegui obteve a ponto de ser eleito para seu Conselho Geral no II Congresso, em 1929, era fundamental no sentido de garantir um respaldo político internacional. Entrementes, a Confederação Sindical Latino-americana, instrumento sindical do Comintern, também representava um garantidor político no processo de formação da Confederação Geral dos Trabalhadores Peruanos. Não se quer dizer aqui que a aproximação de Mariátegui a esses organismos era feita com base apenas em interesses próprios, mas, sim, que o fortalecimento da organização dos trabalhadores no Peru apresentava-se como que vinculada a um estreitamento de laços internacionais.

22 A polêmica entre Mariátegui e Haya de la Torre é um dos temas que mais chamaram a atenção aos estudiosos de ambos. Apesar do trabalho em conjunto por muitos anos, as divergências tornaram-se inconciliáveis quando Haya decidiu, de maneira unilateral, transformar seu projeto de frente única anti-imperialista, a Aliança Popular Revolucionária Americana (APRA), em um partido político. Por trás dessa atitude, estavam as diferentes concepções da luta anti-imperialista e a própria validade do marxismo enquanto método de análise para a compreensão da realidade peruana. Para uma maior compreensão dessa discussão, ver Galindo (1996). 


\section{CONCLUSÃO}

Estudar a relação estabelecida entre um intelectual marxista e a Revolução Russa não é tarefa das mais fáceis. Ao longo dos anos, a obra de Mariátegui constantemente foi alvo de disputas políticas, em que sempre se tentou realizar uma leitura de seu legado à luz dos projetos de quem o lia. ${ }^{23}$ Assim, não é de se espantar que possam ser encontradas caracterizações que se enquadrem nas mais distintas tradições no interior do marxismo.

Embora não se queira negar a validade que porventura possa ter alguma discussão nesse sentido, o certo é que o autor morreu em 1930, ocasião em que muitas dessas discussões mal haviam germinado nem sequer ainda existiam. Como qualquer conjectura além daquelas que estejam calcadas nos textos é aventura do pesquisador, buscou-se investigar o texto e dar voz ao autor, mostrando a evolução de seu pensamento ao longo dos anos.

De modo geral, acredita-se que os escritos de Mariátegui podem ser compreendidos e ajudam a elucidar o penoso trabalho de divulgação e defesa do legado soviético em um momento marcado pela desinformação e pela furiosa cruzada anticomunista, da qual o próprio autor foi vítima inúmeras vezes. Ainda que os textos analisados tenham um caráter propagandístico, é possível dizer que neles se expressam concepções teóricas e políticas que podem ser vistas em outras análises e polêmicas. Assim, ao lado de seus escritos, a influência soviética também pode ser encontrada em sua feição de organizador político, cujo trabalho mais profícuo encontra-se na organização de um partido político e de uma central sindical, temas de futuros artigos.

De maneira mais específica, a pesquisa desses textos e artigos pode ajudar a iluminar a discussão em torno da relação entre Mariátegui e o movimento comunista internacional, vínculo que

\footnotetext{
23 Sobre essa disputa ideológica feita em torno do legado de Mariátegui, duas obras ajudam na compreensão. Uma é a consagrada coletânea de textos sobre Mariátegui organizada por José Maria Aricó (1978) e outra é o balanço feito por Leila Escorsim (2006), que pode ser lido em seu terceiro capítulo, intitulado "Mariátegui e o marxismo - as controvérsias". Esse capítulo foi suprimido de seu livro publicado pela editora Expressão Popular, primeira obra integralmente dedicada a estudar o pensamento de José Carlos Mariátegui publicada no Brasil.
} 
algumas vezes esteve permeado por tensionamentos, mas que lhe forneceu importantes referências e se mostrou de fundamental relevância para a formação de seu horizonte político e cultural. Aos pesquisadores, ainda cabe a tarefa de realizar esse balanço de forma mais acurada e calcada em fontes, visto que as principais referências que imperam hoje do Brasil são Michael Löwy (2005) e Alberto Flores Galindo (1982), as quais tendem a enfatizar demais os conflitos entre as partes, embora deva ser reconhecida a imensa qualidade de ambos os autores e suas obras, indispensáveis a qualquer um que deseje compreender um pouco mais do pensamento do marxista peruano.

Por fim, apresentar o entendimento de Mariátegui acerca da Revolução Russa ajuda-nos a compreender um pouco mais do acontecimento histórico de maior impacto no século passado e que se estende até os correntes dias, em que completa seu centenário. A leitura do peruano dos acontecimentos à época em que aconteciam e sua interpretação levam-nos, também, a reflexioná-los consoante os atuais problemas de nosso mundo, que, infelizmente, insistem, nesse sentido, em parecer tanto aos enfrentados por Mariátegui, há algumas décadas.

\section{REFERÊNCIAS}

ARICÓ, J. M. Mariátegui y los origenes del marxismo latinoamericano. México: Cuadernos de Pasado y Presente, 1978.

ESCORSIM, L. Mariátegui: vida e obra. São Paulo: Expressão Popular, 2006.

GALINDO, A. F. La agonía de Mariátegui: la polémica com la Komintern. Lima: Desco, 1982.

Un viejo debate: el poder (La polémica Haya - Mariátegui). In: Tiempo de plagas. Lima: Concytec, 1996.

KOVAL, B. A grande revolução de outubro e a América Latina. São Paulo: Alfa-omega, 1990.

LÖWY, M. Por um socialismo indo-americano. Rio de Janeiro: UFRJ, 2005.

MARIÁTEGUI, J. C. Mariátegui Total. Tomo I. Lima: Amauta, 1994a. 
Mariátegui Total. Tomo II. Lima: Amauta, 1994b.

Sete ensaios de interpretação da realidade peruana. São Paulo: Expressão Popular, 2010.

PERICÁS, L. B. (org.). Revolução Russa: história, política e literatura. São Paulo: Boitempo, 2012.

José Carlos Mariátegui e o Brasil. Estudos Avançados, São Paulo, v. 24. n. 68 , p. $335-361.2010$.

VANDEN, H. Mariátegui: influencias en su formación ideológica. Lima: Amauta, 1975. 